\title{
Particulate nutrient fluxes over a fringing coral reef: relevant scales of phytoplankton production and mechanisms of supply
}

\author{
Alex S. J. Wyatt ${ }^{1,2, *}$, Ryan J. Lowe ${ }^{1,3}$, Stuart Humphries ${ }^{4}$, Anya M. Waite ${ }^{1,2}$ \\ ${ }^{1}$ The Oceans Institute, M470, The University of Western Australia, 35 Stirling Highway, Crawley 6009, Western Australia \\ ${ }^{2}$ School of Environmental Systems Engineering, M015, The University of Western Australia, 35 Stirling Highway, \\ Crawley 6009, Western Australia \\ ${ }^{3}$ School of Earth and Environment, M005, The University of Western Australia, 35 Stirling Highway, Crawley 6009, \\ Western Australia \\ ${ }^{4}$ Department of Biological Sciences, University of Hull, Cottingham Road, Kingston-upon-Hull HU6 7RX, UK
}

\begin{abstract}
Seasonal observations of phytoplankton uptake at Ningaloo Reef, Western Australia, reinforce the importance of particulate organic nitrogen (PON) and carbon (POC) in reef nutrient budgets and identify wave action and the dynamics of regional currents (over a range of temporal and spatial scales) as important factors determining plankton supply to the reef. Phytoplankton uptake rates, calculated from declining chlorophyll a concentrations as water moved over the reef, appeared to be near the physical limits of mass transfer. Phytoplankton-derived PON flux of 2 to $5 \mathrm{mmol} \mathrm{N} \mathrm{m} \mathrm{N}^{-2} \mathrm{~d}^{-1}$ was on the order of that typical for dissolved $\mathrm{N}$ uptake - confirming that particle feeding may supply the $\mathrm{N}$ missing in reef $\mathrm{N}$ budgets - while POC flux of 14 to $27 \mathrm{mmol} \mathrm{C} \mathrm{m}^{-2} \mathrm{~d}^{-1} \mathrm{was}^{-}$ on the order of net community metabolism. Phytoplankton supply was highly variable at daily-toseasonal time scales in response to the dynamics of a regional current system dominated by the downwelling-favourable Leeuwin Current (LC). Acceleration of the LC in the austral autumn may supply as much phytoplankton to the reef as sporadic upwelling associated with the Ningaloo Current (NC) in summer. The ocean catchment concept is introduced as a basis for examining the spatial scale of pelagic processes influencing benthic systems: every day, Ningaloo may completely consume the phytoplankton over $87 \mathrm{~km}^{2}$ of LC water, compared to only $20 \mathrm{~km}^{2}$ of NC water. Production within this catchment appears insufficient to maintain offshore phytoplankton concentrations, and advection of remotely sourced production into the catchment is required to balance reef uptake. A functional dependence by reef organisms on externally sourced ocean productivity increases the potential scale at which human- or climatically induced changes may affect reef communities and suggests that processes such as changes in offshore currents and plankton communities require further consideration in reef-level biogeochemistry.
\end{abstract}

KEY WORDS: Ningaloo Reef · Nutrient budget · Oceanographic forcing $\cdot$ Particulate organic carbon · Particulate organic nitrogen · Leeuwin Current · Ocean catchment · Upwelling

\section{INTRODUCTION}

Coral reefs represent biogeographic centres of biodiversity and provide a large range of ecosystem goods and services (Moberg \& Folke 1999). Although we know that coral reefs are under increasing pressure from climate change, acidification, habitat destruction and overfishing (Hoegh-Guldberg et al. 2007), we are still learning much about the factors controlling their productivity and function at an ecosystem level (Atkinson \& Falter 2003). The relative importance of external and internal processes and nutrient sources for coral reef function has a long history of debate. Although it is now recognised that reefs may not be the selfsufficient ecosystems (Hatcher 1997) that early atoll studies had suggested (Sargent \& Austin 1949, Odum 
\& Odum 1955, Johannes et al. 1972), the significance of external nutrient delivery is yet to be fully quantified in the field. The role of processes such as upwelling (Andrews \& Gentien 1982), cross-reef advection of large volumes of water (Erez 1990, Atkinson 1992, Charpy 2001), groundwater and terrestrial runoff (Risk et al. 1994, Umezawa et al. 2002), $\mathrm{N}$ fixation (in adjacent waters, within reef sediments and by symbionts; D'Elia \& Wiebe 1990, Sammarco et al. 1999, Lesser et al. 2007) and internal wave activity (Wolanski \& Delesalle 1995, Leichter et al. 1998, 2003) all require further consideration. This is especially so in the context of particulate nutrient fluxes, with most reef-level biogeochemistry focusing on dissolved nutrient fluxes (e.g. Atkinson \& Falter 2003, Hamner et al. 2007). There is increasing evidence, however, that suspended particles may play a more significant role in reef trophodynamics that previously considered. Reef organisms have been shown to be capable of removing a range of particles from the water column under laboratory conditions, with more recent studies underscoring the importance of smaller particles $(<100 \mu \mathrm{m})$, particularly pico- and nanoplankton (Ferrier-Pages et al. 1998, Ribes et al. 2003, Houlbrèque et al. 2004b). The few field estimates of particle depletion have supported these laboratory results, implying trophic links between the benthos and surrounding water column processes (Yahel et al. 1998, Fabricius \& Dommisse 2000, Houlbrèque et al. 2006).

Quantitative estimates of the significance of particulate input in terms of $\mathrm{C}$ and $\mathrm{N}$ fluxes are scarce. Estimates of $\mathrm{C}$ flux have varied significantly, largely due to differences in the range of particle sizes sampled, from an order of magnitude lower than net productivity of the benthic community (Glynn 1973, who neglected the smaller pico- and nanoplankton) to the same order of magnitude (using conversion factors from chlorophyll a [chl a], Ayukai 1995; directly, Fabricius \& Dommisse 2000). The latter 2 studies demonstrated that particulate $\mathrm{C}$ flux is likely to be higher when smaller size fractions are considered; however, fluxes may vary widely between different communities. Few studies have estimated particulate $\mathrm{N}$ flux in the field, either directly or indirectly. However, rates of dissolved inorganic N uptake on reefs are generally low relative to the C:N:P ratio of organisms (Atkinson \& Falter 2003) and particle N concentrations are high relative to dissolved nutrient concentrations, suggesting that particulate uptake is a potentially significant source of N. Several studies have confirmed that, under laboratory conditions, utilisation of particulate $\mathrm{N}$ may be as high as that of dissolved $\mathrm{N}$ (e.g. Ribes et al. 2003, Houlbrèque et al. 2004b). Such importance of particulate $\mathrm{N}$ adds weight to the theory that heterotrophic feeding by reef organisms may play a significant role in energy budgets, calcification (Fer-
rier-Pages et al. 2003, Houlbrèque et al. 2004a) and resilience to stressors (Grottoli et al. 2006, Palardy et al. 2008). Despite this, the dynamics of particles (including factors controlling their supply and incorporation into reef food webs) have received little attention, making the ecological significance of heterotrophy in coral reef systems, and by extension the biological oceanography of surrounding waters, especially difficult to quantify.

Quantifying particle fluxes in situ is often constrained by complex reef-scale habitat zonation and hydrodynamics (Crossland et al. 1991, Atkinson \& Falter 2003). Attempts have been made to quantify particle flux in idealised systems, such as along channels (Fabricius \& Dommisse 2000) or through perforated reefs (Fabricius et al. 1998); however, as Genin et al. (2009) point out, the flux inferred from these unique systems may be idiosyncratic. In a natural reef, variable flows and biogeochemical processes over different communities (e.g. Miyajima et al. 2007) and depths, in addition to variable lagoonal residence times, vertical shearing of velocities and open lateral boundaries (Genin et al. 2009), can all confound attempts to calculate oceanic supply to, and particle removal by, a reef. As a result, a so-called control volume (CoVo) approach is often the most effective means of estimating the uptake of particulate nutrients by a reef (Genin et al. 2002, 2009). This approach depends on determining the flux of particles into and out of a defined control volume that contains the active uptake area (the reef), with any differences assumed to be due to uptake by the reef community. However, the CoVo approach does have restrictions: (1) reef hydrodynamics at the site must not be too complex (i.e. the upstream and downstream measurements occur at the ends of real streamlines); (2) overall the reef is viewed as a black box, eliminating the capacity for inferences regarding reef-scale variability in fluxes that are likely to occur among different reef zones (e.g. Miyajima et al. 2007); (3) the capacity for the simultaneous production and consumption of various components of suspended particulate matter within the CoVo are ignored (similar to simultaneous dissolved $\mathrm{P}$ uptake and remineralisation, Atkinson 1992), and particle uptake rates are therefore likely to be underestimated if reef production is not accounted for (Houlbrèque et al. 2006); and (4) a CoVo must be selected that is representative of the reef as a whole in terms of composition and processes if results are to be scaled beyond the CoVo.

In the present study, we examined phytoplankton fluxes across the fore reef, reef flat and lagoon of a reef section at Sandy Bay, Ningaloo Reef, on the northwest coast of Western Australia $\left(22^{\circ} 02^{\prime} \mathrm{S}, 113^{\circ} 55^{\prime} \mathrm{E}\right.$; Fig. 1a), controlling for the factors that typically limit CoVo particle flux studies described above. The reef section is geometrically and hydrodynamically simple and well characterised, with sampling in different reef 



Fig. 1. Sandy Bay, Ningaloo Reef, Western Australia. (a) Consistent shoreward cross-reef flow revealed by GPS drifters released shoreward of the surf zone (blue tracks) and outside the reef (yellow tracks); black arrows indicate direction of flow (see Fig. 2 for more details on hydrodynamics). (b) Reef zonation and bathymetry along black transect line in (a) derived from hyperspectral imagery. (c) Representative images of the benthic habitat demonstrate the shift from the tabulate hard coral dominated reef flat (Stn 3), to patch reef (Stn 4) and sandy lagoon along the flow path (Stn 5). Numbers 1 to 6 denote fixed water column sampling stations (see Fig. 4) 
zones accounting for reef-scale variability in the benthic community. By focusing on phytoplankton, the influence of reef-level particle production on flux estimates is minimised, since the residence time over the reef is insufficient for pelagic phytoplankton productivity to significantly alter their concentrations, i.e. we were able to examine a predominately allocthonous particle source. Although the study focused on Sandy Bay, Ningaloo Reef as a whole is comprised of up to 50 functionally similar circulation cells along its length. In this system, consistent cross-reef flow resulting from wave-setup (Symonds et al. 1995. Lowe et al. 2009) in the surf zone drives oceanic water across the reef and into the lagoon. The reef-lagoon circulation cell thus represents a natural flume for quantifying particle flux in situ: this simple, well-defined natural flow is coupled with a natural reef community without the limitations associated with an experimental flume (e.g. limited dimensions, edge effects and limited forcing).

In addition to being a natural flume, the reef-lagoon circulation cells effectively link oceanographic- and reef-scale processes along the length of the reef. At $\sim 290 \mathrm{~km}$ long, Ningaloo Reef is one of the largest fringing reef systems in the world. The reef is close to shore, with a lagoon width as low as $200 \mathrm{~m}$ (average $2.5 \mathrm{~km}$, Cassata \& Collins 2008), but receives little to no terrestrial inputs from the adjacent arid desert other than infrequent storm discharge (Cassata \& Collins 2008). The reef also lies very close to the edge of the continental shelf, which is at its narrowest along the Australian coast, and is thus impacted by 2 opposing coastal current systems that vary seasonally in relative strength: (1) the southward-flowing Leeuwin Current (LC), which is low nutrient and suppresses upwelling (Pearce 1991, Johannes et al. 1994), and (2) a northward-flowing (upwelling-favourable) Ningaloo Current (NC) that often dominates inshore of the LC in the summer months during periods of relatively strong southerly winds (Woo et al. 2006a). Ningaloo Reef thus experiences sporadic and transient upwelling during the austral summer. No direct comparison of oceanographic conditions in the 2 opposing seasons has been undertaken adjacent to the reef; however, sampling in LC and NC waters during the upwelling season has suggested that seasonal sporadic upwelling can increase nitrate concentrations 10 -fold, from $<0.1$ to 2-6 $\mu \mathrm{M}$, and more than double primary production, from 100-500 mg C m $\mathrm{d}^{-1}$ to $850-1300 \mathrm{mg} \mathrm{C} \mathrm{m}^{2} \mathrm{~d}^{-1}$ (Hanson et al. 2005). This backdrop of dynamic regional oceanography means that Ningaloo Reef is an ideal location for examining the role of external oceanographic processes in reef biogeochemistry. While the reef-lagoon section at Sandy Bay exhibits relatively consistent circulation patterns during the year, nutrient loading (both dissolved and particulate) is thought to vary significantly among seasons and perhaps over relatively short time scales (e.g. days to weeks) in response to oceanographic forcing (Feng \& Wild-Allen 2009). In the present study we examined the significance of reef-level phytoplankton flux at Ningaloo Reef in the context of regional oceanographic processes.

\section{MATERIALS AND METHODS}

Study site. Sandy Bay, Ningaloo Reef, is located near the centre of the North West Cape (Fig. 1a) and is the site of the most comprehensive reef hydrodynamic studies conducted on Ningaloo (Hearn \& Parker 1988, Lowe et al. 2008). The reef morphology is characterised by a $\sim 1: 30$ fore reef slope that rises to a shallow $(\sim 1.5 \mathrm{~m})$ reef flat stretching $\sim 500 \mathrm{~m}$ shoreward of the surf zone (Fig. 1b). The reef flat is separated from shore by a $\sim 500 \mathrm{~m}$ wide, $\sim 2$ to $3 \mathrm{~m}$ deep lagoon. Surface waves of $\sim 1$ to $3 \mathrm{~m}$ are incident to Ningaloo throughout the year; wave-setup generated by these breaking waves in the surf zone (Symonds et al. 1995, Lowe et al. 2009) elevates the mean water level in the vicinity of the reef crest, establishing a pressure gradient that drives a cross-reef flow. Water driven into Ningaloo's lagoons by wave-setup returns back to the ocean through gaps (channels) in the reef (Fig. 1a). The mean tidal amplitude at Ningaloo is relatively small $(\sim 0.5 \mathrm{~m})$, such that at Sandy Bay the circulation is dominated by wave forcing, i.e. tides modulate the flow across the reef but it very rarely reverses (see 'Results: hydrodynamics').

The reef composition at Sandy Bay is typical of that observed elsewhere on Ningaloo Reef. In general terms, the reef is characterised by a poorly studied fore reef environment rising to a reef crest with high cover of encrusting coralline algae $(\sim 80 \%$, Cassata \& Collins 2008), a reef flat with high cover of tabulate scleractinian corals (Acropora spp., often $>100 \%$ cover) and large rubble and sand patches, a patchy back reef habitat including large stands of branching staghorn Acropora spp. and a sandy lagoonal habitat interspersed with algal patches. Visual surveys of percentage cover within $1 \mathrm{~m}^{2}$ quadrats undertaken in May 2007 revealed that the dominant average cover $(>10 \%)$ in the reef flat zone at Sandy Bay was contributed by rubble $(24 \%)$, sand $(23 \%)$ and tabulate Acropora spp. coral (18\%) (A. S. J. Wyatt unpubl. data). High $(\sim 10 \%)$ but patchy cover by bottlebrush Acropora spp. and soft corals was also evident. The lagoon was $58 \%$ sand and $26 \%$ algae (largely Sargassum sp.). The fore reef composition at Ningaloo is generally poorly known (Cassata \& Collins 2008). Quantification of the reef slope community via quadrats was not undertaken directly in the present study, as it is 
logistically difficult by SCUBA diving due to water depths, strong currents and large swells. From previous studies, the reef slope to about $30 \mathrm{~m}$ depth is characterised by spur-and-groove formations supporting a diverse hard coral assemblage dominated by tabulate Acropora spp., with soft coral, Millepora, sponges and macroalgae (Cassata \& Collins 2008). Visual observations around Stns 1 and 2 (20 and $15 \mathrm{~m}$ depth, respectively; Fig. 1a,b) suggest increasing dominance by Porifera (sponges) and Alcyonaria (sea whips and gorgonians) with increasing depth (Colquhoun et al. 2007), but scleractinian corals (Acropora spp.) continued to dominate live cover in this depth range.

Field experiment. Four separate field experiments of $\sim 3$ to 6 wk duration were conducted in both May and November 2007 and 2008. During each experiment, Eulerian water column sampling was regularly conducted at 6 fixed stations along the dominant cross-reef flow path (see below and Fig. 1a), the exception being November 2007 when fixed sampling was only possible at Stns 3 and 4. The reef slope stations (Stns 1 and 2) were located so as to be as distant as possible from the potential influence of channel outflow. Lagrangian sampling was also undertaken in November 2007 and May 2008 along flow paths (at 20 min intervals) taken by 2 GPS-tracked cruciform drifters (see 'Hydrodynamics'; Austin \& Atkinson 2004), adjacent to the drifters as they traversed the reef.

Due to time required to collect and analyse water samples, it was generally not possible to sample all stations each day; instead, a portion of the stations were typically sampled on alternate days. The exception was during the November 2008 experiment where most stations (i.e. Stns 1 to 4 ) were sampled simultaneously on most days.

Hydrodynamics. During each experiment, mean currents within the circulation cell were monitored continuously using a moored $2 \mathrm{MHz}$ Nortek Aquadopp profiler (ADP) deployed on the reef flat between Stns 3 and 4. Hourly depth-averaged current speeds $U_{\mathrm{r}}$ across the reef were computed from raw 3-dimensional velocity profiles ( $0.1 \mathrm{~m}$ bin size) recorded every $15 \mathrm{~min}$. Time series of the local water depth $h_{\mathrm{r}}$ inferred from the ADP pressure sensor were used to calculate a volumetric flow rate per unit reef width $q_{\mathrm{r}}=U_{\mathrm{r}} h_{\mathrm{r}}$.

In addition to moored current measurements, Lagrangian observations of water circulation were made through the periodic deployment of 2 drifters (see above). The drifters were initially released $\sim 50 \mathrm{~m}$ shoreward of the surf zone and typically followed until they reached the channel entrance (Fig. 1a). A limited number of deployments were also possible outside the reef (near Stn 2), with the drifters allowed to travel through the surf zone and over the reef (Fig. 1a). The drifters extended $\sim 0.5 \mathrm{~m}$ below the water surface and were thus just able to traverse the reef flat during spring low tides.

In May and November 2008, a 1 MHz Nortek AWAC current profiler/directional wave gauge was deployed on the fore reef in $\sim 20 \mathrm{~m}$ of water near Stn 1 (Fig. 1a). Hourly wave spectra were computed using raw time series of water surface variability collected using acoustic surface tracking. These spectra were used to compute time series of significant wave height $H_{\mathrm{s}}$ and peak period $T_{\mathrm{p}}$ for the waves incident to the reef.

Sampling and analysis. At each sampling location, 2 replicate 201 surface water samples were taken and filtered within $2 \mathrm{~h}$ for chl $\mathrm{a}$ and particulate nutrient concentrations. For total chl a analysis, 11 samples were filtered onto Whatman GF/F filters and stored frozen until overnight extraction in $8 \mathrm{ml} 90 \%$ acetone within $10 \mathrm{~d}$ of collection. For analysis of the $>5 \mu \mathrm{m}$ fraction, 21 of seawater were filtered onto $5 \mu \mathrm{m}$ Nitex mesh. All samples were analysed for chl a with a fluorometer (Turner Designs T700) without grinding. Samples were acidified with $10 \% \mathrm{HCl}$ to correct for phaeopigments, and chl a concentrations were calculated according to Parsons et al. (1984). All analyses were performed using total chl a data except where explicitly stated (i.e. the small to large cell ratio analysis).

POC and PON values were obtained by filtering $4 \mathrm{l}$ of water through precombusted $\left(500^{\circ} \mathrm{C}, 6 \mathrm{~h}\right)$ Whatman GF/F filters. Samples were acidified to remove carbonates using either acid fumigation or direct drop-wise addition of $1 \mathrm{M} \mathrm{HCl}$. Samples were stored frozen and desiccated until analysis. Samples were combusted in tin capsules using an elemental analyser (ANCA-GSL, Europa Scientific) to $\mathrm{N}_{2}$ and $\mathrm{CO}_{2} . \mathrm{N}_{2}$ and $\mathrm{CO}_{2}$ were purified by gas chromatography and the $\mathrm{N}$ and $\mathrm{C}$ elemental composition determined by continuous flow-isotope ratio mass spectrometry (20-20 IRMS, Europa Scientific).

It has been found that acid fumigation is insufficient to eliminate erroneously high POC values resulting from carbonate contamination in shallow-water coral reef samples due to significant sand resuspension (A. S. J. Wyatt et al. unpubl. data). Consequently, POC data obtained using acid fumigation and direct addition of $\mathrm{HCl}$ showed varying levels of carbonate sand contamination. Samples with $\delta^{13} \mathrm{C}$ values above $-9 \%$ were considered to contain carbonate sand and were excluded from POC analysis. Both methods of acidification were found to have no significant effect on PON (A. S. J. Wyatt et al. unpubl. data).

Phytoplankton $\mathrm{C}$ and $\mathrm{N}\left(\mathrm{POC}_{\mathrm{p}}\right.$ and $\mathrm{PON}_{\mathrm{p}}$, respectively) were estimated by correcting for non-photosynthetic components of total POC and PON using the same correction conventionally applied to POC (Banse 1977).

Phytoplankton uptake rates. Across the reef (from Stns 1 to 4 ), where the cross-reef flow was approxi- 
mately 1-dimensional (see below), the volumetric flow rate $q$ (not the current speed $U$ ) should be roughly conserved (Lowe et al. 2009). This was supported by paired drifter releases along the study transect (e.g. Fig. 1), which were not observed to significantly diverge or disperse; given that these drifter paths represent fluid streamlines, the volume of flow between adjacent streamlines would be roughly conserved (Kundu \& Cohen 2002). From the measured chl a concentration $C_{i}$ at each station $i$, the phytoplankton uptake rate $m_{i}\left(\mathrm{mg} \mathrm{m}^{-2} \mathrm{~d}^{-1}\right)$ between each pair of sampling stations can thus be estimated as:

$$
m_{i}=q \frac{\Delta C_{i}}{\Delta x_{i}}
$$

where $\Delta C_{i}=C_{i}-C_{i+1}$ is the concentration difference between adjacent sites and $\Delta x_{i}=\left|x_{i}-x_{i+1}\right|$ is the distance between stations. Note that positive uptake values correspond to a removal of phytoplankton. In practice, given that it was generally not possible to sample all sites on a single day, $m$ was calculated using the average chl a profile across the reef over consecutive $2 \mathrm{~d}$ periods and the average flow rate $q$ during this time. To investigate spatial variability in $m$, values were calculated for 4 distinct regions: (1) fore reef (Stns 1 to 2), (2) reef crest including the surf zone (Stns 2 to 3), (3) reef flat (Stns 3 to 4), and (4) lagoon (average of Stns 4 to 5 and 5 to 6 ). Finally, for the case where particle uptake by the benthos is physically controlled (i.e. mass transfer limited, Sanford \& Crawford 2000; Ribes et al. 2003), uptake is often related to the water column concentration $C$ as $m=S C$, where $S$ is a particle uptake coefficient $S\left(\mathrm{~m} \mathrm{~s}^{-1}\right)$.

Statistical analysis. Statistical analysis was performed in SPSS v17.0. A general linear model ANOVA was used to check for significant differences between groups after confirming homogeneity of variance using Levene's test. Post hoc differences were examined with Fisher's LSD. Proportional data were arcsine transformed.

\section{RESULTS}

\section{Hydrodynamics}

During May 2008, significant wave heights $H_{\mathrm{s}}$ ranged from 0.8 to $2.5 \mathrm{~m}$ (Fig. 2b) and varied between 1 and 3 m during May 2007 and November 2008. For all experiments, the depth-averaged current speed across the reef flat $U_{\mathrm{r}}$ (between Stns 3 and 4) varied from $\sim 10$ to $30 \mathrm{~cm} \mathrm{~s}^{-1}$ (Fig. 2c). Moreover, currents at this location were oriented directly across the reef (deviating on average $<10^{\circ}$ from the shore-normal direction) and never reversed (Fig. 2d), including during periods with ebbing spring tides (Fig. 2a).


Fig. 2. Hydrodynamic data for May 2008. (a) Variation in water depth over daily tidal cycle and between neap and spring tides on the reef flat; (b) significant wave height $\left(H_{\mathrm{s}}\right)$ incident to the reef measured in the vicinity of Stn 1 (see Fig. 1a); (c) crossreef current velocities $\left(U_{\mathrm{r}}\right)$ on the reef flat; these were always positive (shorewards from the ocean across the reef flat) and varied most markedly with changing wave heights; and (d) east-north components of velocity showing that currents never reversed (solid line represents the shore-normal, crossreef orientation and dotted line represents components required for flow to reverse). Data from May 2007 and November 2008 present the same picture of unidirectional cross-reef flow driven by wave forcing

Water therefore roughly flows along a transect from Stns 1 to 6 (total transect length $\approx 3000 \mathrm{~m}$ ). Given the typical current speeds in this circulation cell $(\sim 10$ to $\left.30 \mathrm{~cm}^{-1}\right)$, the residence time of water in the reef- 
lagoon system (from entering the reef to exiting the channel) would be $\sim 2$ to $6 \mathrm{~h}$. Wave breaking in the surf zone is clearly the dominant hydrodynamic forcing mechanism driving the circulation, with the cross-reef current speed $U_{\mathrm{r}}$ increasing roughly linearly with the incident wave height $H_{\mathrm{s}}$ (Fig. 3). There was a strong correlation between $U_{\mathrm{r}}$ and $H_{\mathrm{s}}$ observed for all experiments $\left(\mathrm{r}^{2}=0.64, F_{1,353}=627.2, \mathrm{p}<0.001\right)$, indicating that a reasonable estimate of the currents can also be made from measurements of $H_{\mathrm{s}}$ alone in this predominantly wave-driven flow environment.

A total of 29 paired drifter releases across the 4 experimental periods confirmed the current meter observations and revealed a persistent and steady circulation pattern in the reef-lagoon system, with a shoreward flow across the reef flat and a return flow out the channel (Fig. 1a). On one occasion the drifters were allowed to cross the reef crest through the surf zone and move across the reef (Fig. 1a). This flow pattern was evident under a range of wind conditions with little deviation even under strong winds (e.g. 13 $\mathrm{m} \mathrm{s}^{-1}$ ).

Table 1. Number of replicate water samples $(2 \times 201)$ collected during each of the 4 field experiments for Eulerian (totals and samples per station) and Lagrangian sampling

\begin{tabular}{|lccccccccc|}
\hline \multirow{2}{*}{ Experiment } & \multirow{1}{*}{ Total } & \multicolumn{1}{c}{ Eulerian- } & Lagrangian \\
\cline { 3 - 7 } & & 1 & 2 & 3 & 4 & 5 & 6 & \\
\hline May 2007 & 46 & 8 & 8 & 7 & 10 & 8 & 5 & 0 \\
Nov 2007 & 8 & 0 & 0 & 6 & 2 & 0 & 0 & 14 \\
May 2008 & 27 & 5 & 5 & 6 & 6 & 4 & 1 & 12 \\
Nov 2008 & 41 & 8 & 9 & 10 & 10 & 2 & 2 & 0 \\
Total & 122 & 21 & 22 & 29 & 28 & 14 & 8 & 26 \\
\hline
\end{tabular}



Fig. 3. Significant relationship between cross-reef current velocities $\left(U_{\mathrm{r}} \mathrm{cm} \mathrm{s}^{-1}\right.$, positive towards shore) measured on the reef flat and the significant wave height $\left(H_{\mathrm{s}}, \mathrm{m}\right)$ measured on the fore reef $\left(\mathrm{r}^{2}=0.64, F_{1,353}=627.2, \mathrm{p}<0.001\right)$. Line represents the best least-squares fit: $U_{\mathrm{r}}=6.5 H_{\mathrm{s}}+5.0$

\section{Phytoplankton: spatial and temporal variability}

Phytoplankton concentrations were markedly depleted as water flowed over the reef. During each field season the mean chl a concentration profile along the transect (Fig. 4a) showed a decline of 50 to $60 \%$ as water moved from the fore reef (Stn 1) to the back reef (Stn 4), yet remained relatively constant through the lagoon (Stns 4 to 6). In November 2007, Eulerian sampling was only possible at Stns 3 and 4, but as shown in Fig. 4, chl a concentrations were similar at both stations to corresponding values in November 2008. Lagrangian observations demonstrated similar patterns of chl a depletion as water moved over the reef flat, with associated uptake rates in good agreement with Eulerian estimates on the reef flat (see below and Table 3). Concomitant with the decreases in chl a over the reef flat was an increase in phaeophytin concentrations (Fig. 4b), indicative of chlorophyll breakdown (reviewed by Jeffery et al. 1997). Phaeophytin concentrations followed a pattern approximating the inverse
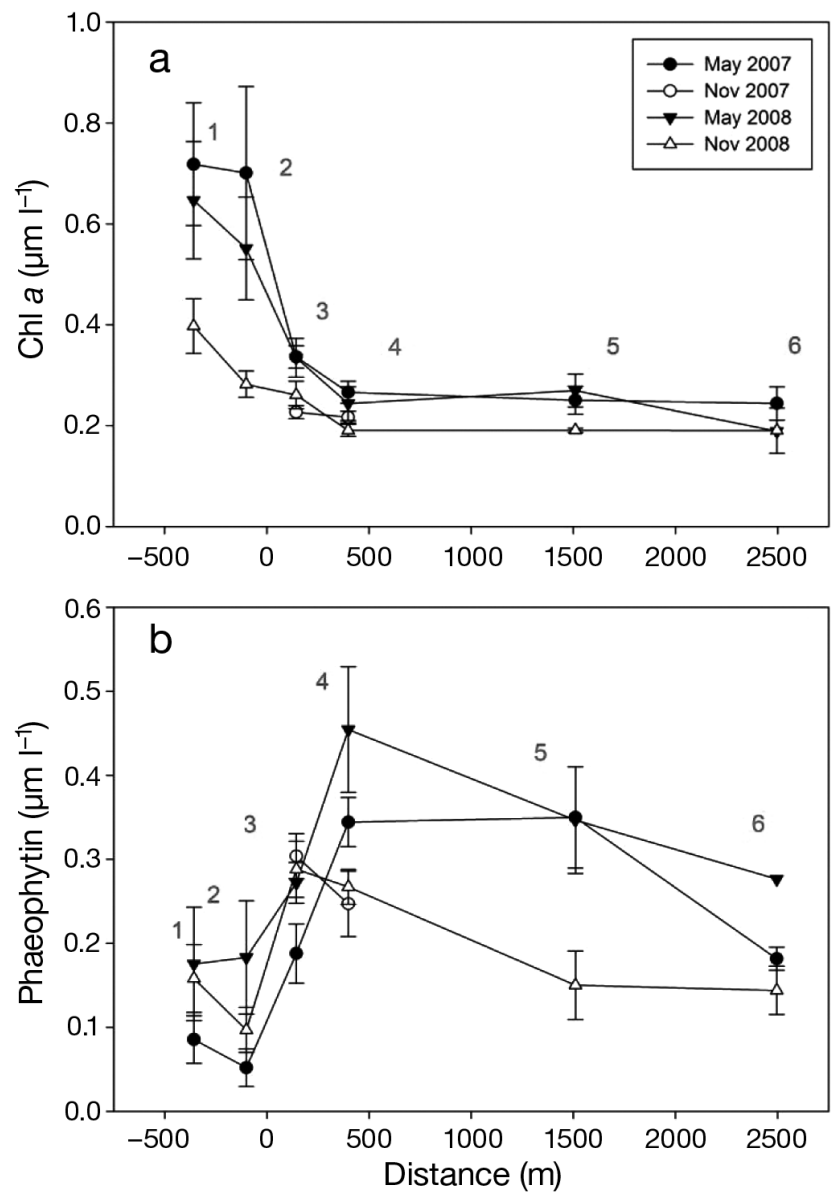

Fig. 4. Eulerian sampling showing (a) chlorophyll a (chl a) and (b) phaeophytin concentrations in water flowing over Ningaloo Reef in May and November 2007 and 2008. Numbers: sampling stations as in Fig. 1a. Means \pm SE, $n$ as per Table 1 
of chl $a$, with phaeophytin increasing by a factor of $\sim 3$ to 5 at Stn 4, after which it declined in the lagoon.

Phytoplankton cells were predominately small, with an average of $\sim 83 \%$ of total chlorophyll in oceanic waters (Stns 1 and 2) contributed by cells $<5 \mu \mathrm{m}$ (Table 2). There was a significant difference in the arcsine-transformed proportion of small phytoplankton between the full field seasons (May 2007, May and November 2008), due to a lower proportion of small cells in May $2008\left(F_{2,94}=8.599, \mathrm{p}<0.001\right)$, particularly inside the reef. The proportion of small plankton remained relatively constant within the reef (Stns 4 to 6: $\sim 79 \%$ in May 2007, 60\% in May 2008 and $87 \%$ in November 2008) and there were no significant differences between reef zones or a significant interaction term between season and zones in the 2-way ANOVA model.

Marked temporal variability in phytoplankton supplied to the reef was evident at a range of temporal scales. At the seasonal scale, chl a concentrations outside the reef (Stn 1) were very similar between both May experiments $\left(\sim 0.7 \mu \mathrm{g} \mathrm{l}^{-1}\right)$, but were much lower during the November 2008 experiment $\left(\sim 0.4 \mu \mathrm{g} \mathrm{l}^{-1}\right)$. At the time scale of individual experiments (weekly) variation was also evident; during the periods when sampling outside the reef was possible, chl a concentrations varied markedly in time by a factor of $\sim 5$ (typically ranging from 0.2 to $1.0 \mu \mathrm{g} \mathrm{l}^{-1}$; Fig. 5). Although the corresponding lagoon chl a levels increased with offshore concentrations, the variation in lagoonal concentrations during experiments was relatively small ( 0.1 to $0.3 \mu \mathrm{g}^{-1}$ ). Marked temporal variability sometimes also occurred over a time scale of just days, as evident during sampling in November 2008 (Fig. 6a). The initially high chl a levels outside the reef $\left(\sim 0.6 \mu \mathrm{g} \mathrm{l}^{-1}\right)$ dropped in a matter of only a few days to $\left(\sim 0.2 \mu \mathrm{g} \mathrm{l}^{-1}\right)$, then gradually recovered to $\sim 0.6 \mu \mathrm{g} \mathrm{l}^{-1}$ during the final week of the experiment. There was some evidence that these declines were related to the influence of the LC, with lower concentrations aligning with a shift to warmer (Fig. 6c) flow to the south (Fig. 6b) at Stn 1 (Fig. 1a). Conversely, the northward, colder flow prevailing during most of November 2008 is indicative of NC water (Fig. 6b,c).



Fig. 5. Phytoplankton (chl a concentration) measured on the fore reef (Stn 1) versus the that measured inside the lagoon (average of Stns 4-6), separated by field season, showing a consistent relationship between upstream and downstream concentrations across seasons. Dotted line is 1:1 relationship and solid line represents the best least-squares fit: $y=0.16 x+$ $0.13\left(\mathrm{r}^{2}=0.62, \mathrm{p}<0.001, \mathrm{n}=20\right)$

\section{Phytoplankton uptake}

The depletion of phytoplankton was pronounced during passage over the reef crest and the concomitant increase in chl a breakdown (phaeophytin concentrations; Fig. 4b) supports that chl a was being consumed. The time scale of passage over the reef ( 2 to $6 \mathrm{~h}$ total, $<1 \mathrm{~h}$ over the active reef area) suggests that phytoplankton cell growth and death processes are unlikely factors in the changes in chl a observed (e.g. Fabricius \& Dommisse 2000).

Phytoplankton uptake rates $m$ were calculated for each of the 4 regions (Eq. 1). Average phytoplankton uptake rates for all experiments revealed that uptake only occurred over regions in the system covered by coral communities (Table 3): $\sim 8 \mathrm{mg} \mathrm{m}^{-2} \mathrm{~d}^{-1}$ for the fore reef, $\sim 4 \mathrm{mg} \mathrm{m}^{-2} \mathrm{~d}^{-1}$ for the reef crest, $\sim 6 \mathrm{mg} \mathrm{m}^{-2} \mathrm{~d}^{-1}$ for the reef flat and $\sim 0 \mathrm{mg} \mathrm{m} \mathrm{m}^{-2} \mathrm{~d}^{-1}$ within the lagoon. Lagrangian observations were in very close agreement

Table 2. Phytoplankton $(<5 \mu \mathrm{m})$ during each of the 4 field experiments and at each sample station. Means \pm SE $\%, \mathrm{n}$ as per Table 1 . '-' indicates no data available







Fig. 6. Temporal variability in (a) cross-reef chl a distribution (corresponding to Stns 1 to 4 ) at a daily scale during November 2008 showing (b) alongshore current direction (north-east current positive, line denotes zero) and (c) temperature recorded at Stn 1 (line denotes mean). Error bars in (a) denote differences between replicate water samples. Shaded bars in (b) and (c) highlight 10-11 and 17-18 November, respectively with uptake rates obtained from Eulerian measurements over the reef flat (Table 3). The pattern of decreasing uptake across the reef was generally consistent between experiments (Fig. 7a), although in May 2007 there was highly variable uptake at the reef crest leading to a significant interaction between experiment and reef zone terms in the ANOVA model $\left(F_{6,124}=2.693, \mathrm{p}=0.018\right)$. Consequently, experiments were analysed independently. Fore reef uptake rates were significantly higher than those on the reef flat during May and November 2008 and those in the lagoon for all 3 experiments (May 2007: $F_{3,54}=6.829$, $\mathrm{p}=0.001$; May 2008: $F_{3,29}=15.40, \mathrm{p}<0.001$; November 2008: $\left.F_{3,41}=13.01, \mathrm{p}<0.001\right)$. Reef crest uptake was also significantly higher than in the lagoon during May 2008. Analysis of individual zones revealed no significant differences in uptake rates between experiments except for lower uptake rates on the reef flat during November $2008\left(F_{2,35}=11.36, \mathrm{p}<0.001\right)$.

To evaluate the total phytoplankton removal rate $M$ by the 3 reef-covered sections (per unit of alongshore reef width, excluding the lagoon where uptake was negligible), $m$ was spatially integrated according to:

$$
M=\sum_{i=1}^{3}\left(m_{i} \Delta x_{i}\right)
$$

This gives $M$-values of 5000,7600 and $2900 \mathrm{mg} \mathrm{m}^{-1}$ $\mathrm{d}^{-1}$, for the May 2007, May 2008 and November 2008 experiments, respectively.

Given the temporal variability in chl a profiles in Fig. $6 a$, the total rate of particle removal $M$ also has the potential to vary on a time scale of days to weeks. Using the 5 profiles from Fig. 6a and Eqs. (1) \& (2), the temporal variability in $M$ during the November 2008 sampling period can be calculated (Fig. 8). Initially on 7 to 8 November, the relatively high chl a concentrations outside the reef led to a value of $M=7900 \mathrm{mg} \mathrm{m}^{-1}$ $\mathrm{d}^{-1}$. This is higher than the average uptake during May 2008. The rate of particle removal then dropped to $\sim 1000 \mathrm{mg} \mathrm{m}^{-1} \mathrm{~d}^{-1}$ on 10 to 11 November, gradually increasing during the following week to $\sim 4000 \mathrm{mg} \mathrm{m}^{-1}$ $\mathrm{d}^{-1}$ which is comparable to the average May 2007 rate.

Particle uptake coefficients $S$, computed as $S=m / C$, where the concentration is taken as the mean value

Table 3. Phytoplankton uptake rate $m\left(\mathrm{mg} \mathrm{chl} \mathrm{a} \mathrm{m} \mathrm{m}^{-2} \mathrm{~d}^{-1}\right)$, uptake coefficient $S\left(\mathrm{~m} \mathrm{~d}^{-1}\right)$ and corresponding phytoplankton particulate organic nitrogen $\left(\mathrm{PON}_{\mathrm{p}}\right)$ and carbon $\left(\mathrm{POC}_{\mathrm{p}}\right)$ flux $\left(\mathrm{mmol} \mathrm{m}^{-2} \mathrm{~d}^{-1}\right)$ determined in each reef zone and by Lagrangian sampling over the reef flat. Means \pm SE \%, $\mathrm{n}$ as per Table 1. Dimensionless Stanton numbers $\left(\times 10^{-3}\right)$ are also shown (see 'Discussion')

\begin{tabular}{|lrrrrr|}
\hline Reef zone & \multicolumn{1}{c}{$\mathrm{S}$} & \multicolumn{1}{c}{ PON $_{\mathrm{p}}$} & \multicolumn{2}{c|}{ POC $_{\mathrm{p}}$} & \multicolumn{1}{c}{$S t$} \\
\hline Fore reef & $8.03 \pm 0.79$ & $19.2 \pm 2.0$ & $4.87 \pm 0.48$ & $27.9 \pm 2.7$ & $1.48 \pm 0.15$ \\
Reef crest & $4.10 \pm 1.40$ & $9.33 \pm 3.9$ & $2.48 \pm 0.85$ & $14.2 \pm 4.8$ & $0.720 \pm 0.30$ \\
Reef flat & $5.67 \pm 0.77$ & $21.3 \pm 2.8$ & $3.43 \pm 0.47$ & $19.6 \pm 2.7$ & $1.64 \pm 0.22$ \\
Lagoon & $-0.110 \pm 0.25$ & $-0.278 \pm 1.1$ & $-0.067 \pm 0.15$ & $-0.383 \pm 0.87$ & $-0.021 \pm 0.08$ \\
Lagrangian & $5.49 \pm 1.1$ & $20.2 \pm 4.6$ & $2.72 \pm 0.68$ & $15.6 \pm 3.9$ & $1.56 \pm 0.35$ \\
\hline
\end{tabular}





Fig. 7. (a) Mean particle uptake rate $\left(m, \mathrm{mg}\right.$ chl $\left.a \mathrm{~m}^{-2} \mathrm{~d}^{-1}\right)$ measured for each field experiment, calculated for the fore reef (between Stns 1 and 2), reef crest including the surf zone (between Stns 2 and 3), reef flat (between Stns 3 and 4) and lagoon (between Stns 4,5 and 5,6). (b) Corresponding particle uptake coefficients $\left(S, \mathrm{~m} \mathrm{~d}^{-1}\right)$

between the adjacent sections, are shown in Fig. $7 \mathrm{~b}$. As for $m$, there was a significant interaction between experiment and reef zone $\left(F_{6,114}=3.304, \mathrm{p}=0.005\right)$. In general, uptake coefficients were highest on the fore reef and reef flat, averaging $\sim 19$ and $21 \mathrm{~m} \mathrm{~d}^{-1}$, respectively (Table 3 ). During all experiments, $S$ was negligible in the lagoon. In May 2007, uptake coefficients were significantly higher on the fore reef and reef flat $\left(F_{3,52}=7.903, \mathrm{p}<0.001\right)$. In May 2008, they were lower (negligible) in the lagoon $\left(F_{3,25}=10.62, \mathrm{p}<0.001\right)$ with no other differences between zones. In November 2008, $S$ was significantly higher on the fore reef relative to all other zones and also on the reef flat relative to the lagoon $\left(F_{3,37}=13.95, \mathrm{p}<0.001\right)$. Analysing by reef zone, there were no significant differences between experiments, apart from lower uptake coefficients on the reef flat during November $2008\left(F_{2,33}=\right.$ 8.190, $\mathrm{p}=0.001$ ).



Fig. 8. Temporal variability in total phytoplankton removal rate per unit alongshore reef width $(M)$ during November 2008

\section{Phytoplankton nutrient uptake (POC and PON)}

In order to estimate nutrient fluxes due to the phytoplankton uptake observed, chl a concentrations were correlated with direct measurements of POC and PON. Cross-reef particulate production complicates direct calculation of POC and PON uptake and examination of only the phytoplankton proportion of nutrient flux is an effective proxy for examining allocthonous (oceanderived, as opposed to reef-produced) particulate nutrients.

There was a significant relationship between PON and chl $a\left(\mathrm{r}^{2}=0.305, F_{1,98}=42.95, \mathrm{p}<0.001\right)$ that revealed a PON:chl a ratio of $8.48 \pm 1.3$. There was no significant difference in the PON-chl a relationship between May 2007, May 2008 and November 2008 (ANCOVA interaction term between chl a and season, $\left.F_{2,94}=2.474, \mathrm{p}=0.09\right)$. A large proportion $(\sim 30 \%)$ of the variation observed in PON could be attributed to variation in phytoplankton concentrations ( $\mathrm{chl} \mathrm{a}$ ), with detritus contributing $6.03 \pm 0.53 \mu \mathrm{g} \mathrm{N} \mathrm{l}^{-1}$ of the total PON. This relationship allows phytoplankton PON $\left(\mathrm{PON}_{\mathrm{p}}\right)$ to be estimated by:

$$
\mathrm{PON}_{\mathrm{p}}=8.48 \mathrm{C}
$$

where $C$ is the chl a concentration. Using the average phytoplankton uptake rates $(m)$ for each reef zone, the equivalent $\mathrm{PON}_{\mathrm{p}}$ flux was then calculated (Table 3). The highest flux was evident over the reef front, equivalent to $\sim 5 \mathrm{mmol} \mathrm{N} \mathrm{m}^{-2} \mathrm{~d}^{-1}$, relative to $\sim 2$ and $3 \mathrm{mmol}$ $\mathrm{N} \mathrm{m}^{-2} \mathrm{~d}^{-1}$ over the reef crest and reef flat, respectively, with negligible flux in the lagoon. The spatially integrated phytoplankton uptake $(M)$ determined using Eq. (2) and converted to $\mathrm{PON}_{\mathrm{p}}$ using Eq. (3) gives $\mathrm{PON}_{\mathrm{p}}=42400,64448$ and $24592 \mathrm{mg} \mathrm{N} \mathrm{m}^{-1} \mathrm{~d}^{-1}$, for the 
May 2007, May 2008 and November 2008 experiments, respectively.

Although there was a significant relationship between phytoplankton and $\mathrm{POC}$, chl a concentrations only explained $\sim 12 \%$ of the variation in POC $\left(\mathrm{r}^{2}=\right.$ $\left.0.117, F_{1,88}=11.66, \mathrm{p}<0.01\right)$. As for PON, there was no significant seasonal difference in the $\mathrm{POC}-\mathrm{chl}$ a relationship (ANCOVA interaction term between chl $a$ and season, $F_{2,84}=0.7284, \mathrm{p}=0.49$ ). The contribution of detritus to POC across all stations in May 2007, May


Phytoplankton POC $\left(\mathrm{POC}_{\mathrm{p}}\right)$ can be estimated as:

$$
\mathrm{POC}_{\mathrm{p}}=41.6 \mathrm{C}
$$

where $C$ is the chl a concentration, leading to an equivalent $\mathrm{POC}_{\mathrm{p}}$ flux for each reef zone (Table 3): $\sim 28 \mathrm{mmol} \mathrm{C} \mathrm{m}^{-2} \mathrm{~d}^{-1}$ on the fore reef compared to $\sim 14$ and $\sim 19 \mathrm{mmol} \mathrm{C} \mathrm{m}^{-2} \mathrm{~d}^{-1}$ on the reef crest and flat, respectively. POC flux was negligible inside the lagoon. The spatially integrated phytoplankton uptake $(M)$ converted to $\mathrm{POC}_{\mathrm{p}}$ using Eq. (4) gives $\mathrm{POC}_{\mathrm{p}}=208,316$ and $121 \mathrm{~g} \mathrm{C} \mathrm{m}^{-1} \mathrm{~d}^{-1}$ for the May 2007, May 2008 and November 2008 experiments, respectively.

\section{DISCUSSION}

Significant supply and assimilation of externally produced particulate matter has a number of implications for our understanding of the function of coral reefs in terms of nutrient dynamics and the influence of oceanographic processes. The simple wave-driven crossreef circulation documented in the present study at Ningaloo suggests that it is an ideal system for quantifying this uptake of ocean-derived material, while the marked seasonal changes in the adjacent ocean make it possible to begin assessing the influence of oceanographic processes on reef-level biogeochemistry.

\section{Phytoplankton fluxes}

The supply of oceanic material to the shallow Ningaloo Reef community is largely wave-driven, with little influence from tide and wind forcing. Based on average flow conditions, wave-driven flow typically leads to a volume flux of $\sim 19000 \mathrm{~m}^{3} \mathrm{~d}^{-1}$ across this reef flat per meter length of coastline; for the entire length of Ningaloo $\left(290 \mathrm{~km}, 85 \%\right.$ reef) this equates to $\sim 4.79 \times 10^{6} \mathrm{~m}^{3}$ of ocean water crossing the reef into the lagoon every day.

The observed phytoplankton uptake within these wave-driven flows was clearly linked to the benthic reef community. Phytoplankton were removed from the water column only over the reef zones, at an average



moval within the sandy lagoon. Lagrangian phytoplankton uptake observations were in close agreement with Eulerian measurements, reinforcing the simple nature of the hydrodynamics that facilitates using a CoVo approach with fixed sampling stations. As observed in previous studies (Fabricius \& Dommisse 2000, Houlbrèque et al. 2006), the residence time over reefs (here $\sim 2$ to $6 \mathrm{~h}$ total, $<1 \mathrm{~h}$ over the active reef) is insufficient to explain differences in phytoplankton between stations based on cell growth rates. Phytoplankton growth rates over the reef based on ammonium uptake rates of $\sim 3 \mathrm{nmol} \mathrm{l}^{-1} \mathrm{~h}^{-1}$ (Kapeli 2007) suggest a doubling time of $>60 \mathrm{~h}$, which clearly places phytoplankton growth as insignificant at the time scale of the crossreef flow. Regardless, significant phytoplankton growth between stations would actually imply even greater particle uptake than we calculated from the declining concentrations between stations.

The specific mechanisms for phytoplankton depletion, such as direct consumption by filter feeders or less direct processes, such as physical trapping in the reef framework and microbial degradation, requires further examination. While purely physical removal based on settling of cells as water moves across the reef is possible, we would expect the greatest settlement to occur in the less energetic back reef and lagoon zones - the observed flux rates were actually lowest in these zones. Furthermore, uptake of chl a was concomitant with an increase in phaeophytin, which is indicative of phytoplankton breakdown and argues against purely physical removal. Whether phytoplankton were degraded due to direct consumption by filter feeders (i.e. grazing), or trapped and then degraded (e.g. in coral mucus, Naumann et al. 2009), it is clear that there is a flux of ocean-derived phytoplankton to the reef which are, presumably, assimilated into the reef food web (i.e. grazing and physical trapping are likely to be biogeochemically equivalent, Genin et al. 2009).

Phytoplankton fluxes were somewhat larger on the fore reef where phytoplankton concentrations were highest. Uptake coefficients, however, suggest as great a potential for uptake by the reef flat community $(S \approx$ $\left.19 \mathrm{~m} \mathrm{~d}^{-1}\right)$ as the fore reef $\left(S \approx 21 \mathrm{~m} \mathrm{~d}^{-1}\right)$. Higher rates of hydrodynamic energy dissipation found on fore reefs may drive higher rates of dissolved nutrient input (Atkinson \& Falter 2003). The more complex flows on the fore reef, which includes an along-reef component, suggest caution may be necessary when drawing conclusions from our estimates of fore reef uptake. Nonetheless, our data suggest that the higher fluxes on the fore reef may simply be due to greater concentrations of phytoplankton in this region, which is consistent with theories that the fore reef is the most biogeochemically active zone of the reef and where most reef formation occurs (Atkinson \& Falter 2003, Nakamura \& Nakamori 2007). 
The observed uptake coefficients $S$ over the reef ( 9 to $21 \mathrm{~m} \mathrm{~d}^{-1}$ ) are comparable to those reported for dissolved nutrients on reefs, 2 to $15 \mathrm{~m} \mathrm{~d}^{-1}$ for $\mathrm{NH}_{4}{ }^{+}$and $\mathrm{NO}_{3}{ }^{-}$(Atkinson \& Falter 2003), possibly suggesting the uptake was limited by hydrodynamic delivery processes (i.e. mass transfer limited). Similar uptake coefficients have been observed in flume studies, with mean ( \pm SD) $S$ values ranging from around $5.4 \pm 1 \mathrm{~m} \mathrm{~d}^{-1}$ (Ribes et al. 2003) for a range of particle sizes to $12.9 \pm$ $6.3 \mathrm{~m} \mathrm{~d}^{-1}$ for picoplankton $(<2 \mu \mathrm{m})$ (Ribes \& Atkinson 2007). In flume experiments using both dissolved and particulate materials, $S$ has been observed to be functionally dependent on the local current speed $U$, such that the dimensionless Stanton number $(S t=S / U)$ is relatively constant between different flow environments (e.g. Baird \& Atkinson 1997). Using St thus accounts for flow-dependent effects on $S$ and therefore allows for more direct comparison between studies. Values for $S t$ can be calculated based on $m$ and $S$ and an average current velocity on the reef flat of $U=$ $0.15 \mathrm{~m} \mathrm{~s}^{-1}$, giving values on the order of $10^{-3}$ (Table 3 ). This is consistent with the $10^{-3}$ to $10^{-4}$ reported for dissolved nutrient uptake on reefs (Atkinson \& Falter 2003) and further suggests that the removal of phytoplankton may be occurring very near to the maximum possible mass transfer limited rate.

Some studies have shown that particle removal rates can actually vary significantly according to particle type, but it is unclear whether this is due to a physical control based on particle size, or a biological control due to preferential grazing by benthic organisms. As detailed above, $S$ values from the flume work of Ribes et al. (2003) suggest that particle uptake is generally higher for smaller particles, with some evidence of preferential removal (e.g. picoplankton over smaller bacteria or larger nano- and microplankton and detrital particles, Ribes et al. 2003; Synechococcus sp. over heterotrophic bacteria or picoeukaryotes, Ribes \& Atkinson 2007). Houlbrèque et al. (2006) were the first to demonstrate that preferential removal of picoplankton can also be observed in the field. Our uptake coefficients ( 9 to $21 \mathrm{~m} \mathrm{~d}^{-1}$ ) were most comparable to those previously determined for picoplankton $(<2 \mu \mathrm{m}), 12.9$ $\pm 6.3 \mathrm{~m} \mathrm{~d}^{-1}$ (Ribes \& Atkinson 2007), suggesting that the bulk of uptake may have been of smaller cells. However, our analysis of size-based phytoplankton uptake was at a lower resolution than that of the previous studies, comparing only large $(>5 \mu \mathrm{m})$ and small cells. Although there was a significant seasonal difference in the ratio of small to large cells, and there appeared to be fewer small cells on average within the reef (especially in May 2008), cross-reef declines in the ratio of small to large cells were not significant - perhaps a reflection of the high variability inherent in ratio measurements. However, smaller size fractions are recognised to be the most abundant particles in oligotrophic waters (Ducklow 1990), e.g. Ribes et al. (2003) observed that $92 \%$ of particulate $\mathrm{N}$ in a flume was composed of picoplankton $(<2 \mu \mathrm{m})$. The greater quantity of small cells supplied to the reef, around $83 \%$ $<5 \mu \mathrm{m}$ (Stns 1 and 2, Table 3), and the fact that the ratio of small to large cells did not increase across the reef, confirms greater uptake occurred in the smaller fractions. Indeed, preliminary evidence from much higher resolution analysis confirms that picoplankton abundance (Prochlorococcus, Synechococcus and larger picoeukaryotes) declined across the reef concomitant with bulk phytoplankton uptake (N. Patten et al. unpubl. data). Even in the absence of preferential uptake, the high abundance of small cells places them as an abundant source in a low nutrient environment. Given the apparent role of picoplankton in reef trophodynamics (see also Yahel et al. 1998, Houlbrèque et al. 2004b, 2006), potential physical and biological controls on preferential uptake of smaller particles in the field would be worthy of more detailed examination.

We finally note that the fate of phytoplanktondeplete lagoon water exiting the channel to the reef slope could ultimately play some role in the overall cross-shelf exchange of phytoplankton between the ocean and reef. Visual observations of fronts adjacent to channels suggest that channel outflow is rapidly mixed with offshore water within a few hundred meters. While the reef slope water at Stn 2 could actually contain some unknown (albeit small) fraction of recirculated lagoon water, the much greater volume of water on the slope relative to the lagoon (due to much greater depth) suggests that lagoon dilution should have a minimal influence on the biogeochemistry of slope water, except directly adjacent to channels. Indeed preliminary analysis of the biogeochemical properties of water at Stn 2 suggest a predominately oceanic origin; POC isotopes $\left(\delta^{13} \mathrm{C}\right)$ and $\mathrm{C}: \mathrm{N}$ ratios increase across the reef and are significantly higher in the lagoon than at Stn 2, which in turn is not significantly different to offshore values (i.e. Stn 1, A. S. J. Wyatt et al. unpubl. data). This argues against a biogeochemically significant influence from channel outflows on slope waters, at least at the distance from channel examined in the present study ( 900 m).

\section{Implications for reef nutrient budgets}

The bulk phytoplankton $\mathrm{N}$ flux (all sizes) documented is comparable to typical uptake rates observed for dissolved N (Atkinson \& Falter 2003) and confirms that particle feeding may supply the $\mathrm{N}$ 'missing' in reef $\mathrm{N}$ budgets (Atkinson \& Falter 2003). Our estimates of phytoplankton PON flux, 2 to $5 \mathrm{mmol} \mathrm{N} \mathrm{m}^{-2} \mathrm{~d}^{-1}$ (Table 3), 
are among the first direct observations of phytoplanktondriven N flux. Fabricius \& Dommisse (2000) found that total suspended particulate matter (SPM) contributed 7 to $15 \mathrm{mmol} \mathrm{N} \mathrm{m} \mathrm{d}^{-1}$ to a soft coral-dominated reef. Our results suggest that phytoplankton alone may play a significant role in $\mathrm{N}$ flux, in addition to that already acknowledged for bulk SPM. In a recent study, Genin et al. (2009) indirectly calculated the $\mathrm{N}$ flux due to phytoplankton in the Red Sea to be on average $2.8 \mathrm{mmol} \mathrm{N} \mathrm{m}^{-2}$ $\mathrm{d}^{-1}$, based on chl $a$ and assumed phytoplankton C:N ratios. This estimate lies within the range of $\mathrm{PON}_{\mathrm{p}}$ flux we have observed. Given the high $\mathrm{N}$ flux from phytoplankton alone, it is clear that particulate material is indeed likely to be a significant component of $\mathrm{N}$ budgets at the reef scale (Atkinson \& Falter 2003).

Uptake rates for other sources of $\mathrm{N}$ are yet to be quantified for Ningaloo Reef, but some preliminary estimates allow comparison to the $\mathrm{PON}_{\mathrm{p}}$ observed. Nitrate and ammonium concentrations averaged $0.55 \pm$ 0.05 and $0.15 \pm 0.01 \mathrm{mmol} \mathrm{m}^{-3}$, respectively, in May 2007 (authors' unpubl. data). Using these concentrations and a typical $S$ value of $15 \mathrm{~m} \mathrm{~d}^{-1}$ (Atkinson \& Falter 2003), the estimated dissolved $N$ uptake for our study site would be 8 and $2.25 \mathrm{mmol} \mathrm{N} \mathrm{m}^{-2} \mathrm{~d}^{-1}$ for nitrate and ammonia, respectively. The phytoplankton flux of $\sim 2$ to $5 \mathrm{mmol} \mathrm{N} \mathrm{m}^{-2} \mathrm{~d}^{-1}$ (Table 3 ) is thus clearly a significant source of $\mathrm{N}$ relative to dissolved species of $\mathrm{N}$. The average $\mathrm{C}: \mathrm{N}$ ratio for typical phytoplankton feeders on this section of Ningaloo is $\sim 8$ (for sponges $7.9 \pm 0.8$, ascidians $8.6 \pm 0.4$ and soft coral $8.3 \pm 0.5$, A. S. J. Wyatt et al. unpubl. data). Based on Eqs. (3) \& (4), the C:N ratio of phytoplankton supplied to the reef can be estimated as $\sim 4.9$. Phytoplankton are thus a rich $\mathrm{N}$ source for these benthic communities.

Phytoplankton flux may also be significant for supplying $\mathrm{C}$ to reef communities. Most reefs are largely autotrophic, including the Ningaloo reef flat (Beaton 2008, J. L. Falter et al. unpubl. data), and particulate C fluxes have typically been considered insignificant. However, given that large amounts of $\mathrm{C}$ are produced and potentially exported from reef systems in organic and inorganic form, such as mucus and carbonate sand, particulate C import deserves further consideration. Integrated net community productivity on the Sandy Bay reef flat was observed to range from 15 to $140 \mathrm{mmol} \mathrm{C} \mathrm{m}{ }^{-2} \mathrm{~d}^{-1}$ (average $75.8 \pm 24$ ) over $4 \mathrm{~d}$ in November 2007 (Beaton 2008, J. L. Falter et al. unpubl. data). The phytoplankton $\mathrm{C}$ flux on the reef flat of $\sim 20 \mathrm{mmol} \mathrm{C} \mathrm{m}^{-2} \mathrm{~d}^{-1}$ is thus significant relative to net community metabolism. Two previous studies have also estimated particulate flux to be on the same order as net community productivity (Ayukai 1995, Fabricius \& Dommisse 2000), although both studies estimated $\mathrm{POC}_{\mathrm{p}}$ indirectly based on chl a $\mathrm{C}$ conversion ratios and the latter focused on bulk SPM uptake (including detri- tus as well as phytoplankton) for a soft coral reef. Fabricius \& Dommisse (2000) suggested that phytoplankton C flux on soft coral reefs is generally an order of magnitude higher than on hard coral reefs: 125 to $720 \mathrm{~g} \mathrm{C} \mathrm{m}^{-2} \mathrm{yr}^{-1}$ based on 3 soft coral studies, compared to $\sim 32$ to $36 \mathrm{~g} \mathrm{C} \mathrm{m}^{-2} \mathrm{yr}^{-1}$ over hard coral (Glynn 1973, Ayukai 1995). The hard coral studies cited may have underestimated phytoplankton C flux, with Glynn (1973) neglecting the most abundant smaller size fractions and Ayukai (1995) using a published $\mathrm{C}$ :chl a ratio of 30 to calculate $\mathrm{POC}_{\mathrm{p}}$ (our data suggested a higher value of $\sim 42$ is more appropriate). Thus reef flat $\mathrm{POC}_{\mathrm{p}}$ uptake reported here, equivalent to $\sim 88 \mathrm{~g} \mathrm{C} \mathrm{m}^{-2} \mathrm{yr}^{-1}$, is higher than previously documented for a hard coral reef and confirms the potential importance of phytoplankton C flux in these systems.

\section{Temporal scales of phytoplankton supply}

Significant uptake of phytoplankton by the reef implies a connection with offshore production and processes occurring at a range of temporal scales, from daily to seasonal. At a seasonal scale, changes in phytoplankton supply to Ningaloo were expected a priori based on knowledge of the oceanographic changes that occur adjacent to the reef during the upwelling season (Hanson et al. 2005, Woo et al. 2006a). The only previous study of upwelling-induced changes adjacent to Ningaloo (Hanson et al. 2005) suggested that increased phytoplankton biomass and productivity would be expected as a result of the upwelling increasing nitrate concentrations. However, Hanson et al. (2005) was based on comparison of LC and NC waters during the upwelling season only (November 2000). The present study is the first to explicitly examine seasonal changes in biological oceanography adjacent to the reef and suggests that phytoplankton supply may actually be highest during the non-upwelling season. Mean $( \pm \mathrm{SE})$ phytoplankton concentrations adjacent to the reef were $0.7 \pm 0.06$ during May compared to $0.4 \pm$ $0.04 \mathrm{\mu g} \mathrm{l}^{-1}$ during November (Fig. 4). Correspondingly, the integrated flux of phytoplankton to the reef during November 2008 (2900 mg m $\mathrm{m}^{-1} \mathrm{~d}^{-1}$ ) was approximately half that observed in May 2007 and 2008 (5000 and $7600 \mathrm{mg} \mathrm{m}^{-1} \mathrm{~d}^{-1}$, respectively).

There are several possible mechanisms for increased phytoplankton biomass during the non-upwelling season in May, including (1) autumn acceleration of the LC transporting nutrients from the north, from below the photic zone, and in eddies and meanders; (2) convective mixing due to cooling and storms activity (Koslow et al. 2008); and (3) changes in near-reef biogeochemistry related to autumn coral spawning (i.e. high concentrations of nutrients). Our observations in 
May 2007 and 2008 were not preceded by any significant increases in storm activity or cooling that would explain higher phytoplankton productivity. Winter storms may be more of a factor in productivity of the LC off southwest Western Australia (e.g. Koslow et al. 2008). Increased pelagic productivity adjacent to the reef in autumn is possible due to increased nutrient availability following mass spawning (e.g. Wild et al. 2008). This occurs in March to April each year (Simpson 1991) and has been implicated in phenomena such as the aggregation of whale sharks Rhincodon typus at the reef from April to May (Taylor 1996, Taylor \& Pearce 1999). Examination of satellite images shows that surface expression of increased phytoplankton in the autumn occurred over a vast (at least 100s of $\mathrm{km}^{2}$ ) spatial scale, and corresponded well with increasing LC flow, placing reef-derived nutrients as an unlikely factor in the autumn bloom and firmly implicating the broad-scale influence of the accelerating LC in reeflevel nutrient fluxes as well as, perhaps, the seasonal dynamics of megafauna such as the whale shark. Interestingly, increased whale shark abundance has also been linked to years of stronger LC flow and phytoplankton biomass, not to upwelling (Wilson et al. 2001, Sleeman et al. 2007).

Upwelling at Ningaloo is considered to be sporadic (Hanson et al. 2005) and requires a significant period of strong southerly winds $\left(\sim 3 \mathrm{~d}\right.$ in excess of $\left.5 \mathrm{~m} \mathrm{~s}^{-1}\right)$ to develop (Willis 2007). It is possible that we did not observe increased phytoplankton concentrations during the upwelling season due to a lack of favourable winds during our November sampling. However, the daily-scale variability in phytoplankton in November was indicative of upwelling. The changes shown in Fig. 6a were also visually evident during diving operations on the fore reef: poor visibility conditions $(<5 \mathrm{~m})$ would alternate with exceptional visibility $(\geq 20 \mathrm{~m})$ over several days. It may be that phytoplankton concentrations were only lower in November on average; while the average total flux of phytoplankton to the reef $(M)$ was lower in November 2008, on some days the flux was as large as the average seen in May ( 8000 mg chl a $\mathrm{m}^{-1} \mathrm{~d}^{-1}$, Fig. 8).

Two principal mechanisms are considered possible in driving the daily-scale variability observed during the upwelling period: changes in the balance between the LC and NC and internal wave activity. The former is best supported by the present study. Changes in wind stress mean that the LC may pulse onto the shelf when the NC weakens, bringing with it water with lower nutrient and phytoplankton concentrations than present in the NC at this time of year. Pulsing of LC water onto the shelf is supported by the shift to southerly flowing (Fig. 6b), warmer (Fig. 6c) water indicative of the LC during periods of reduced phytoplankton concentra- tions (Fig. 6a). The potential role of internal wave activity in temporally variable nutrient supply requires further consideration, especially at shorter time scales than considered in the present study.

\section{Spatial scales of phytoplankton supply}

Given apparently strong external forcing at a variety of temporal scales, it becomes critical to consider the spatial scale over which oceanographic processes may affect reef trophodynamics. While seasonal dynamics in pelagic production off Ningaloo have yet to be adequately resolved, the present study and that of Hanson et al. (2005) demonstrate the potential for Ningaloo to interact with distinctly seasonal regional oceanographic processes. This suggests the potential for mechanistic linkages between the reef and ocean over a vast spatial scale.

With this variable oceanographic backdrop in mind, we can estimate the scale at which changes in phytoplankton biomass and production would likely influence supply to Ningaloo Reef. We postulate the idea of a dynamic oceanographic 'catchment' for reefs, which will vary seasonally depending on both reeflevel processes and variability in regional oceanography (Fig. 9). Although analogous to a river catchment, which has fixed spatial dimensions, the oceanographic catchment must be viewed as dynamic, with dimensions that can vary temporally dependent on offshore production and hydrodynamics.

Uptake along Ningaloo occurs over a length fixed by the length of the reef $\left(L_{\mathrm{r}}\right)$ at a rate $M$ (the spatially integrated phytoplankton uptake rate per unit of alongshore reef width, $\mathrm{mg} \operatorname{chl} \mathrm{a} \mathrm{m}^{-1} \mathrm{~d}^{-1}$, Eq. 2). The total phytoplankton flux to the reef $\left(M L_{\mathrm{r}}\right)$ must be balanced by the available phytoplankton per unit time in offshore waters $\left(A_{C} \bar{C}\right)$, where $\bar{C}$ is the depth-integrated chl a concentration. This balance gives:

$$
A_{C}=\frac{M L_{r}}{\bar{C}}
$$

where $A_{\mathrm{c}}$ is the catchment area per day. If we assume that phytoplankton uptake occurs along the length of Ningaloo at similar rates (i.e. Sandy Bay $M$ is representative) and that $85 \%$ of Ningaloo is composed of reef with similar uptake area as that at Sandy Bay (measurements from aerial photographs indicate $\sim 87 \%$ reef for the $\sim 30 \mathrm{~km}$ surrounding Sandy Bay), this conservatively gives an active uptake length $\left(L_{\mathrm{r}}\right)$ of $246 \mathrm{~km}$ for the whole reef. Using the average $M$ observed in May and November 2008, we obtain a phytoplankton flux $\left(M L_{\mathrm{r}}\right)$ of $19 \times 10^{8}$ and $7 \times 10^{8} \mathrm{mg} \mathrm{d}^{-1}$ for the LC and NC seasons, respectively. Assuming that depth-integrated chl a concentrations $(\bar{C})$ are average at non-upwelling 




Fig. 9. The ocean catchment concept. To maintain phytoplankton concentrations (depth-integrated chl a concentration, $\bar{C}$ ) within the catchment area $\left(A_{c}\right)$, phytoplankton reef uptake $M$ per unit of reef length $L_{\mathrm{r}}$ must be balanced by pelagic production $(P)$ and grazing $(G)$ and advective flux in and out of the catchment, such as by the Leeuwin Current (LC) from the north and Ningaloo Current (NC) from the south

and upwelling values observed by Hanson et al. (2005), the estimated catchment size $A_{\mathrm{c}}$ for both LC and $\mathrm{NC}$ water is $\sim 87$ and $\sim 20 \mathrm{~km}^{2} \mathrm{~d}^{-1}$, respectively (Table 4). This implies that in $1 \mathrm{yr}$, uptake by Ningaloo reef communities could completely consume all phytoplankton in the water column over 7000 to $30000 \mathrm{~km}^{2}$. This is a significant offshore area, especially given that it only applies to the uptake we observed by the reef shallower than $20 \mathrm{~m}$. The catchment area for Ningaloo Reef as a whole, including deeper reef slope communities, would likely be much larger.

Clearly the above approach only provides an estimate of the catchment under static conditions, ignoring the physical and biological factors responsible for maintaining phytoplankton levels in the catchment itself. If we assume that net production is the dominant source replenishing phytoplankton in the catchment (i.e. in the absence of significant LC and NC advection), then the plankton flux to the reef must be balanced by net production in the catchment:

$$
(P-G) A_{\mathrm{C}}=M L_{\mathrm{r}}
$$

So for the catchment sizes calculated with Eq. (5) (Table 4), this implies that cumulative daily net production would have to be equal to depth-integrated chlorophyll concentrations $(\bar{C})$. Assuming that average gross production $(P)$ values observed by Hanson et al. (2005) in LC and NC waters are representative of non-upwelling and upwelling rates (converting from $\mathrm{mg} \mathrm{C} \mathrm{m}^{-2}$ $\mathrm{d}^{-1}$ to $\mathrm{mg}$ chl a $\mathrm{m}^{-2} \mathrm{~d}^{-1}$ using Eq. 4), and that pelagic grazing rates $(G)$ are negligible, it is clear that production is insufficient to maintain the catchments' phytoplankton concentrations. Gross production in the LC of

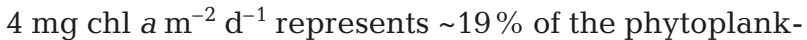
ton required each day by the reef, while in the NC pro-


requirement. So the role of productivity in supporting the reef will depend on the dynamics of the LC and NC, and may be particularly significant for the NC.

Alternatively, the advective flux required to maintain the catchment can be calculated based on the deficit between $\bar{C}$ and net production (assumed to be $P)$. Thus $\sim 17.4$ and $10.9 \mathrm{mg}$ chl a m $\mathrm{m}^{-2} \mathrm{~d}^{-1}$ is required from the LC and NC, respectively. For the catchment areas in Table 4, this equates to $\sim 15 \times 10^{8}$ and $2 \times$ $10^{8} \mathrm{mg} \mathrm{d}^{-1}$. Based on the maximum volume transport $(Q)$ in the LC and NC, $\sim 7$ Sverdrups (Sv) (Godfrey \& Ridgway 1985, Pearce 1991) and $\sim 0.1 \mathrm{~Sv}$ (Woo et al. 2006b), respectively, we can estimate the peak advective fluxes within the 2 currents, $F_{\mathrm{LC}}$ and $F_{\mathrm{NC}}$, using average depth-integrated phytoplankton biomass $\bar{C}$ as per Table 4 and integration depth $d(\sim 100$ and $80 \mathrm{~m}$, respectively, Hanson et al. 2005):

$$
F=\frac{Q \bar{C}}{d}
$$

giving $F_{\mathrm{LC}}=130 \times 10^{9} \mathrm{mg} \mathrm{d}^{-1}$ compared to $F_{\mathrm{NC}}=3.1 \times$ $10^{9} \mathrm{mg} \mathrm{d}^{-1}$. The fluxes required in addition to production to maintain the catchment are thus around 1.2 and $7.0 \%$ of the maximum LC and NC flux, respectively ( $\% F$, Table 4). These maximum fluxes in the LC and NC are also sufficient to completely replenish the catchment in the absence of any local net production. The simplified advective flux considered above indicates that advection of external (remote) sources of

Table 4. Ocean catchment $\left(A_{\mathrm{c}} \mathrm{km}^{2} \mathrm{~d}^{-1}\right)$ for Ningaloo Reef for a catchment dominated by the Leeuwin (LC) and Ningaloo (NC) current. Calculations use depth-integrated phytoplankton biomass $\bar{C}\left(\mathrm{mg} \mathrm{chl} a \mathrm{~m}^{-2}\right)$ and average reef uptake rates


mg chl $a \mathrm{~m}^{-2} \mathrm{~d}^{-1}$ using Eq. 4) is insufficient to maintain $\bar{C}$ in the catchment. The maximum advective flux in the LC and $\mathrm{NC}$ is more than adequate to maintain $\bar{C}$, with the proportion required in addition to $P$ shown $(\% F)$. The proportion of advective flux required is likely to have been underestimated since no loss of phytoplankton due to pelagic grazing $G$ (mg chl a m $\mathrm{m}^{-2} \mathrm{~d}^{-1}$ ) is included in the calculation as it is currently not well quantified for the region

\begin{tabular}{|lccccc|}
\hline Water mass & $\bar{C}^{\mathrm{a}}$ & $M L_{\mathrm{r}}$ & $A_{\mathrm{c}}$ & $P^{\mathrm{a}}$ & $\% F^{\mathrm{b}}$ \\
\hline LC & 21.4 & 19 & 87 & 4 & 1.2 \\
$\mathrm{NC}$ & 35.9 & 7 & 20 & 25 & 7.0 \\
\multicolumn{7}{c}{ a Means in vicinity of Ningaloo Reef Hanson et al. (2005) } \\
'based on maximum volume transport Woo et al. (2006b) \\
\hline
\end{tabular}


phytoplankton into the catchment adjacent to Ningaloo is essential to maintain existing reef uptake rates.

These first estimates of a dynamic ocean catchment suggest that Ningaloo may have ecological connectivity with the surrounding ocean at scales hitherto unconsidered, and provide a mechanistic basis for examining processes that alter the functional scale of reefs, including changes in regional currents and net productivity.

\section{Implications of the ocean catchment}

A dependence of reefs on large-scale, dynamic oceanic catchments has several implications. Firstly, reefs may be even more susceptible to global changes that alter regional oceanography than presently thought. It is recognised that the direct effects of global climate change and ocean acidification may lead to the loss of coral-dominated ecosystems within this century (Hoegh-Guldberg et al. 2007). The role of indirect effects, such as changes in offshore currents and planktonic communities, has not previously been considered. For instance, oceanographic conditions offshore from Ningaloo are driven by climatic conditions that vary seasonally and interannually (Feng et al. 2003). How climate change will alter these conditions, and therefore the production and supply of oceanic material to the reef, is currently unknown. While corals themselves have often been thought to be one of the most sensitive indicators of climate change, planktonic communities may be equally, if not more, sensitive to global change, especially given their short life cycles (Hays et al. 2005, Hooff \& Peterson 2006). Climate change and acidification has the potential to alter both the composition of planktonic communities (e.g. Hooff \& Peterson 2006) and, perhaps more importantly, their quality as a food source. For example, an increase in phytoplankton $\mathrm{C}: \mathrm{N}$ ratios in response to rising $\mathrm{CO}_{2}$ concentrations (e.g. Riebesell et al. 2007, Iglesias-Rodriguez et al. 2008) would reduce the quality of particulate nutrients supplied to reefs. IglesiasRodriguez et al. (2008) observed that C:N ratios in the coccolithophore Emiliania huxleyi increased significantly, from 6.8 to 8.3 , when $\mathrm{CO}_{2}$ concentrations increased between 280 and 750 parts per million by volume. If similar adjustment in $\mathrm{C}: \mathrm{N}$ ratios occurred community wide, and without a concomitant increase in production, the phytoplankton $\mathrm{N}$ flux described in Table 3 would likely be altered; foreseeably, $22 \%$ more plankton would need to be supplied to the reef for the same $\mathrm{N}$ input. These potential indirect effects of climate change and ocean acidification on reef systems require further consideration in order to fully understand the future of coral reefs under various climate change scenarios.

The second implication of the dynamic ocean catchment is its role in sustaining reef biodiversity by supporting reef biota that ultimately depend on ocean supply. The organisms that link reef and ocean through particle uptake may have a disproportionately high significance to a reefs' function, as well as potentially being very susceptible to changes in the surrounding ocean. Likely candidates for particle dependence include cryptic suspension feeders, such as sponges and ascidians (Richter \& Wunsch 1999, Ribes et al. 2005, de Goeij \& van Duyl 2007), and planktivorous fishes (Hamner et al. 1988, Pinnegar \& Polunin 2006, Hamner et al. 2007). Interestingly, visual observations at our site indicate planktivorous fishes concentrate against the reef wall (Stns 2 to 3, Fig. 4a), most noticeably large schools of the dark-banded fusilier Pterocaesio tile and various pomacentrids, perhaps creating the 'wall of mouths' of Hamner et al. (1988). Further work is required to identify which components of the food web play a significant role in the incorporation of particles from the ocean and their susceptibility to oceanographic changes.

Finally, the concept of a dynamic oceanic catchment has broader implications for a range of marine systems and problems, including marine reserve design and the effects of global climate change. Marine reserves designed to protect benthic marine systems may be grossly inadequate if the system is dependent on a large-scale oceanographic catchment that remains unprotected. Similarly, dependence on large-scale oceanographic processes may enhance or ameliorate the effects of global climate change on benthic systems of conservation significance, such as through regional shifts in currents and offshore production. Understanding seasonal changes in an ocean catchment offers the potential to manage the timing of detrimental activities, such as dredging and drilling, in order to minimise the likelihood of negative effects on the catchment and associated reefs. Coral reef biogeochemistry, and many other marine fields, would likely be enhanced by quantifying the role of broad-scale oceanography in local processes, viewing the benthos and surrounding oceanographic regimes as a unified system.

Acknowledgements. We thank J. Erez of The Hebrew University, Jerusalem, for early discussion with A.M.W. We are especially grateful for discussions with J. Falter and M. Atkinson of the Hawaii Institute of Marine Biology over the course of this project. D. Krikke, F. McGregor, S. Hinrichs, N. Patten, A. Chalmers, K. Brooks, D. Kappeli and K. Phlip provided valuable sampling assistance. We also thank W. Klonowski and M. Lynch of Curtin University for providing access to processed hyperspectral bathymetry data. Funding was provided by a Natural Environment Research Council Advanced Fellowship and a grant from the British Ecological Society to S.H., grants from The University of Western Australia, the Faculty of Engineering, Computing and Mathematical Sciences, and the Western Australian Marine Science Institution (Node 3) to A.M.W., an Australian Research Council (ARC) Discovery 
Grant \#DP0663670 to A.M.W. et al., an ARC Discovery Grant\# DP0770094 to R.J.L., and CSIRO Wealth from Oceans funding to A.S.J.W. An early version of this manuscript was improved by comments from P. W. Sammarco and several anonymous reviewers.

\section{LITERATURE CITED}

Andrews JC, Gentien P (1982) Upwelling as a source of nutrients to the Great Barrier Reef ecosystem: A solution to Darwin's question? Mar Ecol Prog Ser 8:257-269

Atkinson MJ (1992) Productivity of the Enewetak flats predicted from mass transfer relationships. Cont Shelf Res 12: 799-807

Atkinson MJ, Falter JL (2003) Coral reefs. In: Black K, Shimmield G (eds) Biogeochemistry of marine systems. CRC Press, Boca Raton, FL, p 40-64

Austin J, Atkinson S (2004) The design and testing of small, low-cost GPS-tracked surface drifters. Estuaries 27: 1026-1029

Ayukai T (1995) Retention of phytoplankton and planktonic microbes on coral reefs within the Great Barrier Reef, Australia. Coral Reefs 14:141-147

Baird ME, Atkinson MJ (1997) Measurement and prediction of mass transfer to experimental coral reef communities. Limnol Oceanogr 42:1685-1693

Banse K (1977) Determining the carbon-to-chlorophyll ratio of natural phytoplankton. Mar Biol 41:199-212

Beaton R (2008) Biogeochemistry of Ningaloo Reef. PhD thesis, University of Western Australia, Perth

Cassata L, Collins LB (2008) Coral reef communities, habitats, and substrates in and near sanctuary zones of Ningaloo Marine Park. J Coast Res 24:139-151

> Charpy L (2001) Phosphorus supply for atoll biological productivity. Coral Reefs 20:357-360

Colquhoun J, Heyward A, Rees M, Twiggs E, Fitzpatrick B, McAllister F, Speare P (2007) Ningaloo Reef Marine Park benthic biodiversity survey. Australian Institute of Marine Science, Perth

Crossland CJ, Hatcher BG, Smith SV (1991) Role of coral reefs in global ocean production. Coral Reefs 10:55-64

D'Elia CF, Wiebe WJ (1990) Biogeochemical nutrient cycles in coral reef ecosystems. In: Dubinsky Z (ed) Coral reefs. Elsevier, Amsterdam, p 49-74

de Goeij JM, van Duyl FC (2007) Coral cavities are sinks of dissolved organic carbon (DOC). Limnol Oceanogr 52: 2608-2617

Ducklow HW (1990) The biomass, production and fate of bacteria in coral reefs. In: Dubinsky Z (ed) Coral reefs. Elsevier, Amsterdam, p 265-289

Erez J (1990) On the importance of food sources in coral reef ecosystems. In: Dubinsky Z (ed) Coral reefs. Elsevier, Amsterdam, p 411-418

Fabricius KE, Dommisse M (2000) Depletion of suspended particulate matter over coastal reef communities dominated by zooxanthellate soft corals. Mar Ecol Prog Ser 196:157-167

Fabricius KE, Yahel G, Genin A (1998) In situ depletion of phytoplankton by an azooxanthellate soft coral. Limnol Oceanogr 43:354-356

Feng M, Wild-Allen K (2009) The Leeuwin Current. In: Liu KK, Atkinson L, Quinones R, Talaue-McManus L (eds) Carbon and nutrient fluxes in continental margins: a global synthesis. Springer, New York

Feng M, Meyers G, Pearce A, Wijffels S (2003) Annual and interannual variations of the Leeuwin Current at 32 degrees S. J Geophys Res Oceans 108:21

Ferrier-Pages C, Allemand D, Gattuso JP, Jaubert J, Rassoulzadegan R (1998) Microheterotrophy in the zooxan- thellate coral Stylophora pistillata: effects of light and ciliate density. Limnol Oceanogr 43:1639-1648

Ferrier-Pages C, Witting J, Tambutte E, Sebens KP (2003) Effect of natural zooplankton feeding on the tissue and skeletal growth of the scleractinian coral Stylophora pistillata. Coral Reefs 22:229-240

Genin A, Yahel G, Reidenbach MA, Monismith SG, Koseff JR (2002) Intense benthic grazing on phytoplankton in coral reef revealed using the control volume approach. Oceanography 15:90-96

Genin A, Monismith SG, Reidenbach MA, Yahel G, Koseff JR (2009) Intense benthic grazing of phytoplankton in a coral reef. Limnol Oceanogr 54:938-951

Glynn PW (1973) Ecology of a Caribbean coral reef: Porites reef-flat biotope. 2. Plankton community with evidence for depletion. Mar Biol 22:1-21

> Godfrey JS, Ridgway KR (1985) The large-scale environment of the poleward-flowing Leeuwin Current, Western Australia: longshore steric height gradients, wind stresses and geostrophic flow. J Phys Oceanogr 15:481-495

Grottoli AG, Rodrigues LJ, Palardy JE (2006) Heterotrophic plasticity and resilience in bleached corals. Nature 440: 1186-1189

Hamner WM, Jones MS, Carleton JH, Hauri IR, Williams DM (1988) Zooplankton, planktivorous fish, and water currents on a windward reef face: Great Barrier Reef, Australia. Bull Mar Sci 42:459-479

> Hamner WM, Colin PL, Hamner PP (2007) Export-import dynamics of zooplankton on a coral reef in Palau. Mar Ecol Prog Ser 334:83-92

Hanson CE, Pattiaratchi CB, Waite AM (2005) Sporadic upwelling on a downwelling coast: phytoplankton responses to spatially variable nutrient dynamics off the Gascoyne region of Western Australia. Cont Shelf Res 25: 1561-1582

Hatcher BG (1997) Coral reef ecosystems: How much greater is the whole than the sum of the parts? Coral Reefs 16: S77-S91

> Hays GC, Richardson AJ, Robinson C (2005) Climate change and marine plankton. Trends Ecol Evol 20:337-344

Hearn CJ, Parker IN (1988) Hydrodynamic processes on the Ningaloo coral reef, Western Australia. In: Choat JH, Barnes D, Borowitzka M, Coll JC and others (eds) Proc 6th Int Coral Reef Symp, Townsville 2:497-502

> Hoegh-Guldberg O, Mumby PJ, Hooten AJ, Steneck RS and others (2007) Coral reefs under rapid climate change and ocean acidification. Science 318:1737-1742

Hooff RC, Peterson WT (2006) Copepod biodiversity as an indicator of changes in ocean and climate conditions of the northern California current ecosystem. Limnol Oceanogr 51:2607-2620

> Houlbrèque F, Tambutté E, Allemand D, Ferrier-Pagès C (2004a) Interactions between zooplankton feeding, photosynthesis and skeletal growth in the scleractinian coral Stylophora pistillata. J Exp Biol 207:1461-1469

Houlbrèque $F$, Tambutté $E$, Richard C, Ferrier-Pagès C (2004b) Importance of a micro-diet for scleractinian corals. Mar Ecol Prog Ser 282:151-160

> Houlbrèque F, Delesalle B, Blanchot J, Montel Y, FerrierPagès C (2006) Picoplankton removal by the coral reef community of La Prevoyante, Mayotte Island. Aquat Microb Ecol 44:59-70

> Iglesias-Rodriguez MD, Halloran PR, Rickaby REM, Hall IR and others (2008) Phytoplankton calcification in a high$\mathrm{CO}_{2}$ world. Science 320:336-340

Jeffery SW, Mantoura RFC, Wright SW (eds) (1997) Phytoplankton pigments in oceanography: guidelines to modern methods. UNESCO, Paris 
Johannes RE, Alberts J, D'Elia CF, Kinzie RA and others (1972) The metabolism of some coral reef communities: a team study of nutrient and energy flux at Eniwetok. Bioscience 22:541-543

Johannes RE, Pearce AF, Wiebe WJ, Crossland CJ, Rimmer DW, Smith DF, Manning C (1994) Nutrient characteristics of well-mixed coastal waters off Perth, Western Australia. Estuar Coast Shelf Sci 39:273-285

Kapeli D (2007) Characterising phytoplankton productivity across the Ningaloo Reef, Western Australia. Honours thesis, The University of Western Australia, Perth

Koslow JA, Pesant S, Feng M, Pearce A and others (2008) The effect of the Leeuwin Current on phytoplankton biomass and production off Southwestern Australia. J Geophys Res Oceans 113:C07050

Kundu PK, Cohen IM (2002) Fluid mechanics. Academic Press, San Diego, CA

> Leichter JJ, Shellenbarger G, Genovese SJ, Wing SR (1998) Breaking internal waves on a Florida (USA) coral reef: A plankton pump at work? Mar Ecol Prog Ser 166:83-97

Leichter JJ, Stewart HL, Miller SL (2003) Episodic nutrient transport to Florida coral reefs. Limnol Oceanogr 48: 1394-1407

- Lesser MP, Falcón LI, Rodríguez-Román A, Enriquez S, Hoegh-Guldberg O, Iglesias-Prieto R (2007) Nitrogen fixation by symbiotic cyanobacteria provides a source of nitrogen for the scleractinian coral Montastraea cavernosa. Mar Ecol Prog Ser 346:143-152

Lowe RJ, Symonds G, Taebi S, Pattiaratchi C, Ivey G, Brinkman R (2008) Hydrodynamics of fringing reef systems. Physics of Estuaries and Coastal Seas (PECS), 14th International Biennial Conference, Liverpool, UK, 25-29 August

> Lowe RJ, Falter JL, Monismith SG, Atkinson MJ (2009) Wavedriven circulation of a coastal reef-lagoon system. J Phys Oceanogr 39:873-893

Miyajima T, Tanaka Y, Koike I, Yamano H, Kayanne H (2007) Evaluation of spatial correlation between nutrient exchange rates and benthic biota in a reef-flat ecosystem by GIS-assisted flow-tracking. J Oceanogr 63:643-659

Moberg F, Folke C (1999) Ecological goods and services of coral reef ecosystems. Ecol Econ 29:215-233

Nakamura T, Nakamori T (2007) A geochemical model for coral reef formation. Coral Reefs 26:741-755

Naumann MS, Richter C, el-Zibdah M, Wild C (2009) Coral mucus as an efficient trap for picoplanktonic cyanobacteria: implications for pelagic-benthic coupling in the reef ecosystem. Mar Ecol Prog Ser 385:65-76

Odum HT, Odum EP (1955) Trophic structure and productivity of a windward coral reef community on Eniwetok Atoll. Ecol Monogr 25:291-320

Palardy JE, Rodrigues LJ, Grottoli AG (2008) The importance of zooplankton to the daily metabolic carbon requirements of healthy and bleached corals at two depths. J Exp Mar Biol Ecol 367:180-188

Parsons TR, Maita Y, Lalli CM (1984) A manual of chemical and biological methods for seawater analysis. Pergamon Press, New York

Pearce AF (1991) Eastern boundary currents of the southern hemisphere. J R Soc West Aust 74:35-45

> Pinnegar JK, Polunin NVC (2006) Planktivorous damselfish support significant nitrogen and phosphorus fluxes to Mediterranean reefs. Mar Biol 148:1089-1099

Ribes M, Atkinson M (2007) Effects of water velocity on picoplankton uptake by coral reef communities. Coral Reefs 26:413-421

Editorial responsibility: Alain Vézina,

Dartmouth, Nova Scotia, Canada
Ribes M, Coma R, Atkinson MJ, Kinzie RA III (2003) Particle removal by coral reef communities: picoplankton is a major source of nitrogen. Mar Ecol Prog Ser 257:13-23

Ribes M, Coma R, Atkinson MJ, Kinzie RA III (2005) Sponges and ascidians control removal of particulate organic nitrogen from coral reef water. Limnol Oceanogr 50: 1480-1489

> Richter C, Wunsch M (1999) Cavity-dwelling suspension feeders in coral reefs - a new link in reef trophodynamics. Mar Ecol Prog Ser 188:105-116

> Riebesell U, Schulz KG, Bellerby RGJ, Botros M and others (2007) Enhanced biological carbon consumption in a high $\mathrm{CO}_{2}$ ocean. Nature 450:545-549

Risk MJ, Sammarco PW, Schwarcz HP (1994) Cross-continental shelf trends in $\delta^{13} \mathrm{C}$ in coral on the Great Barrier Reef. Mar Ecol Prog Ser 106:121-130

> Sammarco PW, Risk MJ, Schwarcz HP, Heikoop JM (1999) Cross-continental shelf trends in coral $\delta^{15} \mathrm{~N}$ on the Great Barrier Reef: further consideration of the reef nutrient paradox. Mar Ecol Prog Ser 180:131-138

Sanford LP, Crawford SM (2000) Mass transfer versus kinetic control of uptake across solid-water boundaries. Limnol Oceanogr 45:1180-1186

Sargent MC, Austin TS (1949) Organic productivity of an atoll. Trans Am Geophys Union 30:245-249

Simpson CJ (1991) Mass spawning of corals on Western Australian reefs and comparisons with the Great Barrier Reef. J R Soc West Aust 74:85-91

Sleeman JC, Meekan MG, Wilson SG, Jenner CKS and others (2007) Biophysical correlates of relative abundances of marine megafauna at Ningaloo Reef, Western Australia. Mar Freshw Res 58:608-623

Symonds G, Black KP, Young IR (1995) Wave-driven flow over shallow reefs. J Geophys Res Oceans 100:2639-2648

Taylor JG (1996) Seasonal occurrence, distribution and movements of the whale shark, Rhincodon typus, at Ningaloo Reef, Western Australia. Mar Freshw Res 47:637-642

Taylor JG, Pearce AF (1999) Ningaloo Reef currents: implications for coral spawn dispersal, zooplankton and whale shark abundance. J R Soc West Aust 82:57-65

Umezawa Y, Miyajima T, Kayanne H, Koike I (2002) Significance of groundwater nitrogen discharge into coral reefs at Ishigaki Island, southwest of Japan. Coral Reefs 21:346-356

Wild C, Jantzen C, Struck U, Hoegh-Guldberg O, Huettel M (2008) Biogeochemical responses following coral mass spawning on the Great Barrier Reef: pelagic-benthic coupling. Coral Reefs 27:123-132

Willis M (2007) Oceanic processes offshore of Ningaloo Reef: transient upwelling. Honours thesis, The University of Western Australia, Perth

Wilson SG, Taylor JG, Pearce AF (2001) The seasonal aggregation of whale sharks at Ningaloo Reef, Western Australia: currents, migrations and the El Nino/Southern Oscillation. Environ Biol Fishes 61:1-11

Wolanski E, Delesalle B (1995) Upwelling by internal waves, Tahiti, French Polynesia. Cont Shelf Res 15:357-368

Woo M, Pattiaratchi C, Schroeder W (2006a) Summer surface circulation along the Gascoyne continental shelf, Western Australia. Cont Shelf Res 26:132-152

Woo M, Pattiaratchi C, Schroeder W (2006b) Dynamics of the Ningaloo Current off Point Cloates, Western Australia. Mar Freshw Res 57:291-301

Yahel G, Post AF, Fabricius K, Marie D, Vaulot D, Genin A (1998) Phytoplankton distribution and grazing near coral reefs. Limnol Oceanogr 43:551-563

Submitted: May 22, 2009; Accepted: January 24, 2010

Proofs received from author(s): April 9, 2010 